\title{
DEVELOPMENT OF LEGAL REGULATION OF THE DIRECT SUPPORT OF AGRICULTURE IN THE PERIOD OF 2004-2013
}

\author{
VÝVOJ PRÁVNEJ ÚPRAVY \\ PRIAMEJ PODPORY POLNOHOSPODÁRSTVA \\ OD R. 2004-2013
}

Lucia PALŠOVÁ*, Pavol SCHWARCZ**

\section{Introduction}

The Common Agricultural Policy is included in the shared competences of the EU and the Member States, and if compared from this point of view it belongs to the most comprehensive policies within the EU. One of the main agendas of the CAP is a direct support for agriculture, which has been paid to farmers in the EU Member States since the MacSharry reform in 1992. Direct support payments in this direction play an important role, and their importance is in addition to farm prosperity, particularly in ensuring adequate income, decent working and living conditions of the agricultural population and especially participation in the conservation and agricultural development of the rural environment, maintaining the rural population as well as maintaining landscape in cultural condition ${ }^{(1)}$. In the field of direct payments the European Union implements the objectives of direct support to agriculture through various instruments, including legislative. Currently, the mostly used regulations by the EU Council are those with a direct effect in all Member States. The implementation of EU regulations is ensured by the Member States through the transposition of the regulations into their own laws.

By joining the EU in 2004, the Slovak Republic accepted all obligations of the EU and started to implement the "acquis communautaire". In the area of direct support by the Council regulation (EC) no. 1782/2003 of 29 September 2003 establishing common rules for direct support schemes under the common agricultural policy and establishing certain support schemes for farmers, as amended, modifying conditions for the establishment of direct support in the new member states, including Slovakia were introduced. The Single Payment Scheme and other additional payments, depending on legislative and financial support applies in the Slovak Republic the period of $2004-2013$

(1) STŘELEČEK, F., LOSOSOVÁ, J. The influence of the Common Agricultural Policy on the economic situation of farms. Vliv Společné zemědelské politiky na ekonomickou situaci zemědelských podniků. In: Economics of Agriculture. 2007. no.1. p. 10 - 18. ISSN 1335-6186.

\section{Abstract (EN)}

The Accession Treaty allowed the new Member States to temporarily establish a different system of payment subsidies in agriculture, compared to the system in force in the old Member States. It is a system of the so called Single Area Payment Scheme (SAPS). This system can be used in the Slovak Republic until the end of 2013. The aim of this paper is to evaluate the rules for the direct support of agriculture within the SAPS and its actual implementation in the period 2004-2013.

\section{Keywords (EN)}

Direct payments, the Single Payment Scheme, complementary national direct payments, acquis communautaire

\section{Abstrakt (SK)}

Zmluva o pristúpení umožnila novým členským štátom možnost' dočasne zaviest' na svojom území iný systém vyplácania podpôr $v$ polnohospodárstve $v$ porovnaní so systémom platným $v$ starých členských štátoch. Ide o systém tzv. jednotnej platby na plochu - Single Area Payment Scheme (SAPS). Tento systém môže SR používat' do konca roku 2013. Cielom príspevku je zhodnotenie právnej úpravy priamej podpory polnohospodárstva a jej reálne uplatňovanie v období $2004-2013$.

\section{Klúčové slová (SK)}

Priame platby, systém jednotnej platby na plochu, doplnkové národné priame platby, aquis communitaire

\section{The acquis communautaire}

The Slovak Republic joined the European Union on May l, 2004, accepting all rights and obligations resulting from the membership in the European communities. Slovakia's accession to the EU started the full implementation of the "acquis communautaire". As the EU's agricultural policy is attributable to common policies, it was necessary for the SR to implement regulations with the direct effect and to transpose the EU directives. In accordance with Art.7 Paragraph 2 of the Constitution of the Slovak Republic adoption of legally binding acts which require implementation shall be made by law 
or government regulation according to Art. 120 paragraph 2. Based on the constitutional empowerment of Art.120 Paragraph 2 of the Constitution of the SR, Act no. 19/2002 was passed regulating the conditions of approximation regulations issuance by the Government of the Slovak Republic, as amended. The Act provides that the Government of the Slovak Republic is under $\S 2$. Art 1 , point k) authorized to issue approximation regulations in the field of agriculture to implement the Europe Agreement concluded between the European Communities and their Member States and the Slovak Republic and to implement certain international treaties under Art 7 Paragraph 2 of the Constitution. Although the law stipulates that the government issues approximation regulations only until Slovakia's accession to the EU, the government continues to issue approximation regulations, which is an advantage considering today's number of guidelines, since otherwise the lawmakers would have to pass the laws rather quickly in the legislative process.

In the field of direct support of agriculture in the specific area is defined by:

- Primary law, in Article 38 - 44, Title III of the Agriculture and Fisheries of the Treaty on the Functioning of the European Union (originally in Article 32 to 38 of the Treaty establishing the European Community). Primary law expresses the objectives of the common agricultural policy and the tools to achieve it.

- Secondary legislation - is implemented by regulations and directives that were during the existence of direct payments amended several times. The reason for the changes in legal acts of direct support was generally the effort to increase the competitiveness of farmers in domestic and export markets and to reduce the outflow of population from rural areas encouraging young farmers to manage the land.

By joining the EU, the Slovak Republic started to apply the Council regulation on direct payments no. 1782/2003 of September 29, 2003 establishing common rules for direct support schemes under the Common agricultural policy and establishing certain support schemes for farmers, as amended and supplemented. The regulation accommodated the system of direct payments in the form of the single payment scheme introduced in 2005, which meant the exemption of direct payments from the farmer's coupling to production - decoupling and its market orientation. Single Payment Scheme based on the basic conditions set out in the EU's Copenhagen summit in $2002^{(2)}$, specifically in the area of production limits and the minimum amount of direct subsidies from the EU.

The scope of the regulation is:

- modification of the Single Payment Scheme, where the direct payment to farmers based on Art. 2 point d) of the regulation is defined as payment granted directly to farmers under an income support scheme listed in Annex I of the regulation,

(2) In December 2002 at the Copenhagen summit negotiations on the accession of the 10 candidate countries to the European Communities ended, while all the chapters were negociated and closed, including agriculture
- treatment of common rules for direct payments under the income support schemes, which refers to the CAP, which are financed by the EAGGF,

- modification of the support schemes for farmers producing durum wheat, protein crops, rice, nuts, energy crops, potatoes grown for starch production, milk, seeds, arable crops, sheep, goat, beef and veal and grain legumes.

Following the changes in terms of direct payments, some supportive regulations were issued such as the Commission regulation (EC) no. 796/2004 of April 21, 2004 laying down detailed rules for the implementation of cross-compliance, modulation and the Integrated Administration and Control System provided in the Council regulation no. 1782/2003 establishing common rules for direct support schemes under the Common agricultural policy and establishing certain support schemes for farmers, as amended and supplemented.

The new Member States, including the SR were in accordance with Art. 143 Council regulation no. 1782/2003 allowed to use during the transition period ( 3 years with a possible extension for another 2 years) special scheme for payment of direct payments to farmers: the Single Area Payment Scheme (Schwarcz, 2007). The Single Payment Scheme (SAPS) was modified by the Commission regulation (EC) no. 2199/2003 of December 16, 2003 regulating the conditions for granting the Single Area Payment Scheme for the Czech Republic, Estonia, Cyprus, Latvia, Lithuania, Hungary, Malta, Poland, Slovenia, Slovakia, as amended and supplemented. SAPS were paid from the European Agricultural Guidance and Guarantee Fund, respectively since 2007 from the European Agricultural Guarantee Fund. Within the simplified system farmers of the new Member States (except Malta and Cyprus) received direct payments from the EU not based on their individual production levels, but on the area of the farm and the amount claimable per hectare, calculated on a national basis. Principles and elements of SAPS were introduced during the accession negotiations in order to offer future Member States a simplified system of direct payments that would simplify and reduce the cost of preparatory work to be carried out before and during the first years after accession. This system allows them to introduce and use only certain tools of Integrated Administration and Control System (IACS).

From the Accession Act of the Slovak Republic to the European Union transitional periods in this matter result in accordance with the schedule of increasing the subsidies, in the case of Slovakia by the Single Area Payment Scheme, expressed as a percentage in relation to Community support for the period $2004-2013$ as well as the obligation to comply with the limits for direct support in the form of Complementary National Direct Payments (Table 1).

\section{Direct payments in Slovakia (2004 - 2013)}

A basic payment that is provided within the SAPS since its introduction in 2004 to the present is the Single Area Payment. 
Table 1: Negotiated schedule of support payments in the new EU Member States

\begin{tabular}{|l|c|c|c|c|c|c|c|c|c|c|}
\hline Contribution (as \% of the EU) / year & 2004 & 2005 & 2006 & 2007 & 2008 & 2009 & 2010 & 2011 & 2012 & 2013 \\
\hline EU contribution & 25 & 30 & 35 & 40 & 50 & 60 & 70 & 80 & 90 & 100 \\
\hline DNPP & 30 & 30 & 30 & 30 & 30 & 30 & 30 & 20 & 10 & 0 \\
\hline Total volume (as \% of the EU) & 55 & 60 & 65 & 70 & 80 & 90 & 100 & 100 & 100 & 100 \\
\hline
\end{tabular}

Source: CAP Monitor, Own Processing

The Single Area Payment shall be provided to the applicant, if agricultural land:

- a) was cultivated as of 30 June 2003,

- b) is at least one hectare of area, and this area can be represented by several blocks of contiguous land parts of the specific type of land with an area of at least 0.3 hectares farmed by one applicant,

- c) has a clearly marked boundaries, unless limited naturally,

-d) is maintained in accordance with Good Agricultural and Environmental Conditions (GAEC).

Since 2004, the Slovak Republic paid Complementary National Direct Payments (CNDP), which were financed by the state budget and the amount was determined by the Budget Law for the given year. CNDP in 2004 - 2006 were financed from the Rural Development Plan funds. Since 2007, all CNDP payments had to be paid solely from national budgets.

CNDPs were paid in 2004 - 2006 for:

- arable crops;

- selected tobacco varieties (varieties of Burley and Virginia);

- hops;

- suckler cows;

- sheep and goats;

- ewes, goats and young sheeps.

Since 2007 there has been a change in direct payments in Slovakia, which in case of SAPS was transposed by the Government regulation no. 81/2007 Coll. on the conditions for granting subsidies in agriculture by Single Area Payment Scheme with effect from March 1, 2007 and as for the special payments the below regulations were issued:

- Government regulation no. 82/2007 Coll. on the conditions for granting subsidies in agriculture by special payment for sugar as amended,

- Government regulation no. 213/2007 Coll. on the conditions for granting subsidies in less favoured areas as amended,

- Government regulation no. 266/2007 Coll. on the conditions for granting subsidies in agriculture by CNDP for large livestock farms as amended,

- Government regulation no. 159/2007 Coll. on the conditions for granting subsidies in agriculture by CNDP in crop production as amended,

- Government regulation no. 158/2007 Coll. on the conditions for granting subsidies in agriculture by payment for energy crops as amended.
Payments were provided as follows:

1. from the European Agricultural Guarantee Fund (EAGF)

- a) Single Area Payment,

- b) special payment for sugar,

- c) special payment for fruits and vegetables.

2. from the European Agricultural Fund for Rural Development (EAFRD)

- a) support for less favoured areas (LFA),

- b) payment for energy crops.

\section{Complementary National Payments}

- a) additional payments per area,

- b) payment for hops,

- c) payment for large livestock units (LU).

The functioning of the new system of direct payments decoupled from production were examined by the Health Check of the CAP in 2008 (the so-called Health Check), as a result of which a new regulation on direct payments (EC) no. 73/2009 of 19 January 2009 was issued establishing common rules for direct support schemes for farmers under the common agricultural policy and establishing certain support schemes for farmers, amending regulations (EC) 1290/2005, (EC) 247/2006, (EC) 378/2007 and repealing (previous) regulation (EC) 1782/2003. Direct payment in accordance with the Council regulation (EC) represents a payment granted directly to farmers under one of the regimes of income support stated in Annex I ${ }^{(3)}$.

From the Accession Act of the Slovak Republic to the European Union transitional periods in this area result relating to compliance with the schedule of increasing subsidies, in the case of Slovakia by the Single Area Payment, expressed as a percentage in relation to Community aid for the period $2004-2013$ as well as the obligation to comply with the limits for direct support in the form of national balancing supplements. Except Bulgaria and Romania, direct payments are introduced in accordance with the following schedule of gradual increasing expressed as a percentage of the amount of payments being applied at present time in other than new Member States (Article 121 of the regulation):

(3) Annex I of the Council regulation (EC) 73/2009 introduced the regimes of support for Single Payment, Single Area Payment Scheme, Durum wheat, Protein crops, Rice, Nuts, Energy crops, Starch potatoes, Seeds, Arable crops, Sheepmeat and goatmeat, Beef and veal, Olive groves, Silkworms, Tobacco, Hops, Sugar beet, cane and chicory used for the production of sugar or inulin syrup, Sugar, beet and cane used for the production of sugar, Fruit and vegetables delivered for processing, Strawberries and raspberries delivered for processing, Fruit and vegetables, Posei, Cotton 
- $60 \%$ in 2009

- $70 \%$ in 2010 ,

- $80 \%$ in 2011 ,

- $90 \%$ in 2012 ,

- $100 \%$ from 2013

Single Area Payment Scheme is allowed by the regulation until December 31, 2013. In Slovakia, the regulation (EC) $1782 / 2003$ was transposed by Government regulation no. 20/2009 Coll. on the conditions for granting subsidies in the form of direct payments to agriculture, as amended (effective 01/02/2009). In accordance with $\S 11$ of the regulation the amount of direct payments determined by a special regulation shall be announced in the Journal of the Ministry of Agriculture and Rural Development. Other direct supports were regulated by:

- Government regulation no. 114/2009 Coll. on the conditions for granting subsidies in agriculture by the complementary national payments for crop production as amended,

- Government regulation no. 266/2007 Coll. on the conditions for granting subsidies in agriculture by the Complementary National Direct Payments for large livestock units as amended.

Payments were provided as follows:

1. from the European Agricultural Guarantee Fund (EAGF)

- a) Single Area Payment,

- b) payment for energy crops,

- c) special payment for sugar,

- d) special payment for fruit and vegetables,

- e) transition payment for tomatoes.

2. From the European Agricultural Fund for Rural Development (EAFRD)

- a) support in less favoured areas (LFA),

- b) agri-environmental payments,

-c) support in the sites of Community importance on agricultural land,

- d) payment for the animal welfare,

- e) payment for the first afforestation of agricultural land,

- f) forestry-environmental payments,

- g) support in the sites of Community importance on forest land.

3. From the State budget - complementary direct payments

- a) complementary area payment,

- b) payment for hops,

- c) payment for large livestock units (LU).

Conditions for direct support in agriculture in Slovakia were later changed by the Government regulation no. 488/2010 Coll. on the conditions for granting support in the form of direct payments to agriculture, as amended, with effect from 1 . 1. 2012. In accordance with $\S 11$ of the regulation the amount of direct payments determined by a special regulation shall be announced in the Journal of the Ministry of Agriculture and Rural Development.
Payments were provided as follows:

1. from the European Agricultural Guarantee Fund (EAGF)

- a) Single Area Payment,

- b) payment for dairy cattle,

- c) special payment for sugar,

- d) special payment for fruit and vegetables,

2. from the European Agricultural Fund for Rural Development (EAFRD)

- a) support in less favoured areas (LFA),

- b) agri-environmental payments,

-c) support in the sites of Community importance on agricultural land,

- d) payment for the animal welfare,

- e) payments for the first afforestation of agricultural land,

- f) forestry - environmental payments,

- g) support in the sites of Community importance on forest land.

Table 1 shows the amount of each type of direct payments in the period $2004-2013$ to one hectare, respectively 1 LU.

As shown in Table 2, the proportion of funds to cover direct payments coming from the EU budget has a growing tendency, resources from the state budget of the SR are paid according to availability (up to a maximum of $30 \%$ of the national co-payments, respectively $20 \%$ in 2010). The total amount of funds to cover direct payments from 2004 to 2010 nearly doubled.

\section{Evaluation of the direct support of agriculture in the period of $2004-2013$}

The application of direct payments in the Slovak Republic has its own performance, while the most common complaint of Slovak farmers consists of the value of direct payments compared to the EU-15. That disproportion amount of direct payments and insufficient or no additional payments from the state, can lead to lower competitiveness of Slovak farmers in the EU internal market.

As a positive feature of the application of direct payments can be considered the fact that farmers from the beginning of operation of the SAPS system respond promptly and use direct payments in sufficient way. It is mainly through the application of direct payments. The staff of regional departments of Agricultural Paying Agency prepared land maps of the LPIS for recipients of direct payments ${ }^{(4)}$. Based on these the applicants are able to specify the application area and the acreage for which the direct payment is claimed. Applications are submitted annually to the regional offices of APA until May 15 of the appropriate year.

4) LPIS - Land Parcel Identification System, is one of the five components of the Integrated Administration and Control System (IACS), is crucial for the identification of agricultural areas and is a prerequisite for providing of subsidies in the agricultural sector from the EU funds. LPIS was built on orthophotomaps. 


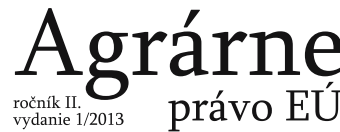

$\underset{\text { Even }}{\text { Agrarian }} \underset{\text { Law }}{\text { A }}$

Table 1: Direct payments in period 2004 - 2013 (in Eur per ha/LU)

\begin{tabular}{|c|c|c|c|c|c|c|c|c|c|}
\hline & 2004 & 2005 & 2006 & 2007 & 2008 & 2009 & 2010 & 2011 & 2012 \\
\hline \multicolumn{10}{|l|}{ EU subsidies } \\
\hline Single Area Payment (€/ha) & 58.71 & 69.7 & 81.65 & 84.75 & 96.64 & 121.60 & 142.40 & 155.36 & 173.95 \\
\hline Special sugar payment (€/ha) & - & - & 466.65 & 516.64 & 562.09 & 546.69 & 273.93 & 597.47 & 597.47 \\
\hline $\begin{array}{l}\text { Payment for growing of energy } \\
\text { crops }(€ / \text { ha) }\end{array}$ & - & - & - & 50.6 & 45 & 45 & - & - & - \\
\hline $\begin{array}{l}\text { Transition payment for tomatoes } \\
(€ / \mathrm{ha})\end{array}$ & - & - & - & - & 772.98 & 831.48 & 477.94 & 538.37 & - \\
\hline $\begin{array}{l}\text { Special payment for fruit and vegeta- } \\
\text { ble }(€ / \text { ha) }\end{array}$ & - & - & - & - & 40.50 & 40.50 & 52.71 & 55.15 & 55.56 \\
\hline Payment for suckler cows $(€ / \mathrm{pc})$ & - & - & - & - & & & 60.84 & 79.16 & 86.15 \\
\hline \multicolumn{10}{|c|}{ Complementary national direct payments } \\
\hline $\begin{array}{l}\text { Payment for crops on arable land } \\
(€ / \text { ha })\end{array}$ & 54.77 & 90.19 & 72.79 & 64.34 & 55.64 & - & - & - & - \\
\hline Additional area payment $(€ /$ ha $)$ & - & - & - & - & - & 32 & - & - & - \\
\hline Payment for hops $(€ /$ ha $)$ & 365.13 & 298.75 & 298.75 & 298.75 & 297.03 & 322.00 & 387.84 & 300.62 & 269.75 \\
\hline $\begin{array}{l}\text { Payment on selected varietes of } \\
\text { tobacco - Burley }(€ / \text { ha })\end{array}$ & 1991.64 & 2489.54 & 2489.54 & 1759.28 & $1.74 € / \mathrm{kg}$ & - & - & - & - \\
\hline $\begin{array}{l}\text { Payment for selected varietes of } \\
\text { tobacco - Virginia }(€ / \text { ha })\end{array}$ & 2655.51 & 3983.27 & 3983.27 & 2190.80 & $2.15 € / \mathrm{kg}$ & - & - & - & - \\
\hline Payment for suckler cows $(€ / \mathrm{pc})$ & 132.78 & 142.73 & 142.73 & - & - & - & - & - & - \\
\hline $\begin{array}{l}\text { Payment for sheeps and goats } \\
(€ / \text { ha })\end{array}$ & 16.6 & 18.59 & 18.59 & - & - & - & - & - & - \\
\hline Payment for livestock units ( $€ / L U)$ & - & - & - & 142.73 & 139.24 & 148 & 143 & $109.5 / 150$ & 35.80 \\
\hline
\end{tabular}

Source: Notifications of the Ministry of Agriculture and Rural development of SR, $2004-2012$

Table 2: Share of EU budget and state budget of SR in direct payments coverage in period 2004 - 2010 (in mil. Eur)

\begin{tabular}{|l|c|c|c|c|c|c|c|}
\hline & 2004 & 2005 & 2006 & 2007 & 2008 & 2009 & 2010 \\
\hline EU budget & 110.4 & 116.1 & 137.4 & 123.9 & 155.6 & 227.0 & 243.7 \\
\hline State budget & 70.0 & 42.1 & 47.6 & 91.4 & 214.8 & 137.1 & 93.9 \\
\hline Total & 180.45 & 158.24955 & 185.01538 & 215.23748 & 370.4 & 364.1 & 337.6 \\
\hline
\end{tabular}

Source: Annual report on agriculture and food industry in the Slovak Republic (2004-2010), exchange rate calculated in accordance with Council regulation 1290/2005, Article 45 paragraph 2, 3

In the context of the introduction of cross-compliance a question was raised regarding responsibility of the maintenance of good agricultural and environmental condition of the area to which the direct payment was granted. As it is evident from the Court's judgment of 13. 12. 2012 in case Maatschap L.A. en D.A.B. Langestraat en P. Langestraat-Troost v. Staatssecretaris van Economische Zaken, Landbouw en Innovatie based on the Article 23 paragraph 1 of the regulation no. $73 / 2009$ breaking the rules of cross-compliance by the beneficiary or the person transferring the agricultural land, leading to a reduction in the total amount of direct payments or to the exclusion of the provision is fully attributable to the farmer, who asked for the support. The Court thus concluded objective responsibility of the applicant of the direct payment, and the "rule of ten months' contained in Article 44 paragraph 3 of the regulation no. 1782/2003, according to which in order to apply for the support, farmers must have the parcels corresponding to the area that relates to the pay- ment claim available for at least ten months, was reduced to one day by the regulation no.146/2008. Therefore, to ensure that farmers received direct payments for the support application, it is sufficient to have the land available on the reference date, in the SR on 15. 5. 2013.

The elements below can be seen as negative: persistent problems of land rights in particular the use of land without leases, land use without a decision on the provisional release of land, the land use due to uncertainty of the parcel borders, fragmentation. That land rights issues hinder the approval of applications for direct payments, as well as their control. The condition of application for SAPS is not submission of proprietary and usufructuary rights to the land to which the direct payment is claimed. It is only the declaration of the land use. If the Agricultural Paying Agency finds out that a double claim could occur they ask all applicants to submit the evidence of ownership or the right of use of the land. In case of dispute, the direct payments to the applicant for 
the entire area will not be paid. The applicant must contact the court which consequently decides about the ownership rights or the right to use the land. Such settlements can be liquidating for some farmers as a lawsuit to determine the ownership rights connected to the direct payments that take several years might cause the inability of a farmer to continue in agricultural production due to the lack of funds and the inability to take a loan.

Another problem is the lack of transparency and lack of understanding of agricultural law, because the European law was added into the Slovak national system, which takes precedence over national law. Translations of the acts and decisions of the Court of Justice of the EU are often of poor quality without translating technical terminology relating to agriculture, which in some cases can cause uncertainty for the recipients of the acts and decisions. Concerning agricultural consultancy, it lacks consistent methodological guidelines and procedures.

\section{References}

1. BANDLEROVÁ, A. et.al. European Union Agrarian Law. Agrárne právo Európskej únie. 1st ed. Nitra: Slovak University of Agriculture, 2007. 218 p. ISBN 978-80-8069-990-1.

2. Notifications of the Ministry of Agriculture and Rural Development on the amount of direct payments for the years $2004-2013$

3. PALŠOVÁ, L., RUMANOVSKÁ L. Common Agricultural Policy and its implementation in conditions of Slovak republic. Spoločná polnohospodárska politika a jej realizácia v podmienkach Slovenskej republiky. 1st ed. Nitra: Slovak University of Agriculture, 2010. 99 p. ISBN 978-80-552-0442-0.

4. SCHWARCZ, P. The use of direct payments in agriculture after the Luxembourg CAP reform of 2003.Využitie priamych platieb v polnohospodárstve po luxemburskej reforme SPP z roku 2003. In: Economics of Agriculture, 2007, no.3. p. 19 - 23. ISSN $1335-6186$.

5. STŘELEČEK, F., LOSOSOVÁ, J. The influence of the common agricultural policy on the economic situation of farms. Vliv Společné zemědelské politiky na ekonomickou situaci zemědelských podniků. In: Economics of Agriculture. 2007. no.1. p. 10 - 18. ISSN $1335-6186$

6. TICHÝ, L., ARNOLD, R., ZEMÁNEK, J., KRÁL R., DUMBROVSKÝ T. European Law. Evropské právo. $4^{\text {th }}$ ed. Praha: C. H. Beck, 2011. 902 p. ISBN 9788074003332

\section{Legal Acts}

Commission regulation (EC) no. 796/2004 of April 21, 2004 laying down detailed rules for the implementation of cross-compliance, modulation and the Integrated Administration and Control System.

Commission regulation (EC) no. 2199/2003 of December 16, 2003 regulating the conditions for granting the Single Area Payment Scheme for the Czech Republic, Estonia, Cyprus, Latvia, Lithuania, Hungary, Malta, Poland, Slovenia, Slovakia, as amended and supplemented.

Council regulation (EC) no. 1782/2003 of 29 September 2003 establishing common rules for direct support schemes under the common agricultural policy and establishing certain support schemes for farmers, as amended.

Council regulation (EC) No 1290/2005 of 21 June 2005 on the financing of the Common Agricultural Policy.

Council regulation (EC) No. 73/2009 establishing common rules for direct support schemes for farmers under the common agricultural policy and establishing certain support schemes for farmers, amending regulations (EC) No. 1290/2005, (EC) No. 247/2006, (EC) No. 378/2007 and repealing regulation (EC) No. $1782 / 2003$.

Government regulation no. 81/2007 Coll. on the conditions for granting subsidies in agriculture by Single Area Payment Scheme with effect from March 1, 2007 and as for the special payments the below regulations were issued:

Government regulation no. 82/2007 Coll. on the conditions for granting subsidies in agriculture by special payment for sugar as amended,

Government regulation no. 213/2007 Coll. on the conditions for granting subsidies in less favoured areas as amended,

Government regulation no. 266/2007 Coll. on the conditions for granting subsidies in agriculture by CNDP for large livestock farms as amended,

Government regulation no. 159/2007 Coll. on the conditions for granting subsidies in agriculture by CNDP in crop production as amended,

Government regulation no. 158/2007 Coll. on the conditions for granting subsidies in agriculture by payment for energy crops as amended.

Government regulation no. 266/2007 Coll. on the conditions for granting subsidies in agriculture by the Complementary National Direct Payments for large livestock units as amended.

Government regulation no. 114/2009 Coll. on the conditions for granting subsidies in agriculture by the complementary national payments for crop production as amended,

Government regulation no. 20/2009 Coll. on the conditions for granting subsidies in the form of direct payments to agriculture, as amended,

Government regulation no. 488/2010 Coll. on the conditions for granting support in the form of direct payments to agriculture, as amended,

Law no. 19/2002, laying down the conditions of Government approximation regulations, as amended,

The Constitution of the Slovak republic no. 460/1992 Coll.

Contact address/ Kontaktná adresa

JUDr. Lucia Palšová, PhD., Slovak University of Agriculture in Nitra, Faculty of European Studies and Regional Development, Department of Law

e-mail: lucia.palsova@uniag.sk

doc. Ing. Pavol Schwarcz, PhD., Slovak University of Agriculture in Nitra, Faculty of European Studies and Regional Development, Department of European Policies

e-mail: pavol.schwarcz@uniag.sk 